\title{
The impact of trade and markets on Chilean Atlantic salmon farming
}

\author{
Exequiel Gonzalez Poblete ${ }^{1} \cdot$ Benjamin M. Drakeford $^{2}$ (D) $\cdot$ Felipe Hurtado Ferreira $^{1} \cdot$ \\ Makarena Garrido Barraza ${ }^{1} \cdot$ Pierre Failler $^{2}$
}

Received: 19 December 2018 / Accepted: 21 May 2019 / Published online: 8 July 2019

(C) The Author(s) 2019

\begin{abstract}
Since the 1980s, aquaculture has developed rapidly around the world, outpacing all other sources of animal protein production. Chile is the largest producer in South America, with an export-driven aquaculture industry. Aquaculture development in Chile has largely focussed on three high-value species (Atlantic salmon, Rainbow trout and Chilean blue mussel). These three species accounted for over $90 \%$ of the volume and value of Chilean exports by 2014. The paper considers the role of trade and markets on Atlantic salmon production in Chile and the role of government regulators and industry to facilitate a further sustainable increase in farmed salmon output. Specifically, we address the opportunities and constraints regarding the impact of trade and markets for further industry expansion. We find that production constraints (e.g. regulation, over-production), marketing constraints (e.g. consumer perception) and environmental constraints (e.g. disease) have led to stagnating and sometimes declining production, preventing Chile from surpassing Norway and becoming the world's largest Atlantic salmon producer. The paper concludes that the signs for further growth are positive in Chile, although to date, it is noted that industry expansion has outpaced developments in infrastructure, regulation and research and development. Most significantly, the industry has been blighted with environmental problems, which has weakened market share in recent years. However, better regulatory practice in Chile in recent years has been seen as positive in international markets. We note that further development in the regulatory framework and continued aspirations to meet certification standards (e.g. Aquaculture Stewardship Council, Global Aquaculture Alliance Certification) could lead to increased market share for Chilean farmed salmon in the future.
\end{abstract}

Keywords Aquaculture $\cdot$ Atlantic salmon $\cdot$ Chile $\cdot$ Markets $\cdot$ Trade

Benjamin M. Drakeford

ben.drakeford@port.ac.uk

Extended author information available on the last page of the article 


\section{Introduction}

The growth in global fish supply ${ }^{1}$ has been more than double the population growth since the end of World War II, increasing per capita supplies from $9.9 \mathrm{~kg}$ in the $1960 \mathrm{~s}$ to $20.3 \mathrm{~kg}$ in 2016 (FAO 2018). Since the share of fish supply from marine capture fisheries has remained relatively stable since the 1990 s, increased per capita consumption in the last three decades has resulted from growth in aquaculture production. Although the rate of growth has declined in recent years, global demand and higher prices have increased the value of global fish exports to USD 152 billion in 2017 (FAO 2018). In fact, aquaculture now accounts for more than $50 \%$ of global fish consumption (direct human consumption), and while developing countries have accounted for over 50\% of supply by volume for some time, 2017 was the first year that developing countries accounted for more than $50 \%$ of the value of global fish exports (FAO 2018).

This trend is expected to continue and is indeed necessary to feed the world's growing population and to continue contributing to food security and economic growth (FAO 2018). The global population is expected to grow to 8.6 billion by 2030 and to 9.8 billion by 2050 (UN 2017). While the growth in aquaculture has undoubtedly increased the availability of sorely needed food supplies in developing countries, there has been little evaluation of the methodologies and indicators used to assess the contribution of the sector to poverty alleviation. As noted by Bene et al. (2016), while fish contributes to nutrition and food security, the contribution of aquaculture development to poverty alleviation is complex and unclear. This has resulted in a lack of consensus on the role of aquaculture in poverty alleviation (AFSPAN 2015 ) and the impact of international seafood trade on food security and poverty alleviation. This represents a concern, given that over $80 \%$ of global fish production ${ }^{2}$ is undertaken in developing countries.

However, as noted by the FAO (2018), the growth in fish production currently provides employment opportunities for nearly 60 million. ${ }^{3}$ Further, aquaculture is estimated to contribute between 0.5 and $2.5 \%$ of global GDP, but in some developing countries, the contribution may be as high as 10\% (Gillett 2009; Allison 2011). While Chile is considered a developed country, this may not be directly interpreted as a trend of reduction in poverty, as inequality in the Chilean economy is considered large. The Gini coefficient for Chile in 2015 was 47.7 (World Bank 2018). As measurements of economic equality, both income equality and income per capita are low for a developed country. Therefore, further expansion of aquaculture may bring positive benefits. The contribution of aquaculture, mainly the Atlantic salmon (Salmo salar) industry, which is second only to Norway in terms of contribution to world supplies, has been significant in the development of the Chilean economy.

In many countries that produce farmed fish, the international trade in food products is dominated by fish and fish products. The combined effect of productivity and market growth has contributed to aquaculture accounting for the world's fastest growing animal-based sector of the last decades. The FAO (2018) estimate that around 35\% of fish output in 2006 is traded internationally and has been as high as $40 \%$ in 2005 (fluctuations dependent on fishmeal production). Tveteras et al. (2012) suggest that the impact of international trade might be much higher, with as much as $78 \%$ of fish products being subject to international trade competition.

\footnotetext{
${ }^{1}$ Global fish supply refers to capture fishery and aquaculture production of finfish and shellfish.

${ }^{2}$ Global fish production refers to all forms of fish production i.e. capture and aquaculture.

${ }^{3}$ Around 40 million jobs are provided by fishing and 20 million jobs by aquaculture (FAO 2018).
} 
Some studies (see, e.g. Beveridge et al. 2013) perceive the international trade in seafood to move large volumes of fish of high nutritional value from poor (i.e. developing) to rich (i.e. developed) countries and thus having a negative impact. Asche et al. (2015), who addressed the impact of exporting seafood and whether this trade outweighs the cost for low-income developing economies, studied the impact of international trade on food security, poverty reduction and economic growth. The authors suggest that in terms of seafood trade, high-value species are exported from low-income to high-income economies and low-value fish are imported to low-income countries. In other words, the trade in seafood products can be considered a quality exchange, reflecting the standard economic assumption that goods are consumed by those who are most willing and able to purchase. Asche et al. (2015) conclude that if one considers the deficit in volume being substantially lower than the deficit in value (and it is), then overall the trade in seafood products is positive for developing economies (if we consider one fish product is substitutable for another) and the economic earnings can be invested in infrastructure, health, education etc. This is an important consideration concerning Chile, as salmon producers are export orientated, with Chilean salmon mainly destined for markets in high-income developed nations, such as the USA, Japan and the EU (EUMOFA 2017). Further, as noted by Ceballos et al. (2018), salmon aquaculture in Chile also creates employment in remote regions and has a significant impact on poverty reduction.

This paper reviews whether trade and markets act as drivers of change in the aquaculture chain and are structured as follows. The first part of the paper considers production and trade patterns in Chilean salmon aquaculture. The second part of the paper considers production constraints with respect to further expansion of the Atlantic salmon industry. We then move on to trade regulations and market constraints, including the industry perspective (interviews undertaken with industry actors). Finally, the paper concludes on potential opportunities and challenges for a further expansion in the Chilean salmon aquaculture industry, based on outputs from a recent project focussing on the role of aquaculture in poverty alleviation, food security and economic growth (EU 7th Framework: Aquaculture for Food Security, Poverty Alleviation and Nutrition (AFSPAN)).

\section{Production and trade patterns in Chilean aquaculture}

Chilean aquaculture grew 158-fold during the last three decades, with annual harvest growing from approximately $7500 \mathrm{t}$ per year in 1985 to $1,192,000 \mathrm{t}$ per year in 2015 . As shown in Fig. 1, finfish accounted for more than $80 \%$ of total national production in the first half of the 2000 s, declining only slightly to $74 \%$ in 2015 . Farmed seaweed production was important during the 1990 s and gave rise to mollusc aquaculture, which has been steadily growing since then.

High-value aquaculture has developed rapidly since the 1990s. Economically, the most important species are Atlantic salmon (Salmo salar), Pacific salmon (Oncorhynchus kisutch), rainbow trout (Onchorynchus mykiss), Chilean blue mussel (Mytilus chilensis) and Gracilaria seaweed (Gracilaria spp), together accounting for more than $90 \%$ of production by volume and value of total Chilean aquaculture exports in 2014 (see Fig. 2).

Figure 3 presents the trade flows for the main species produced in Chile, minus information on transportation, as such data do not exist. 


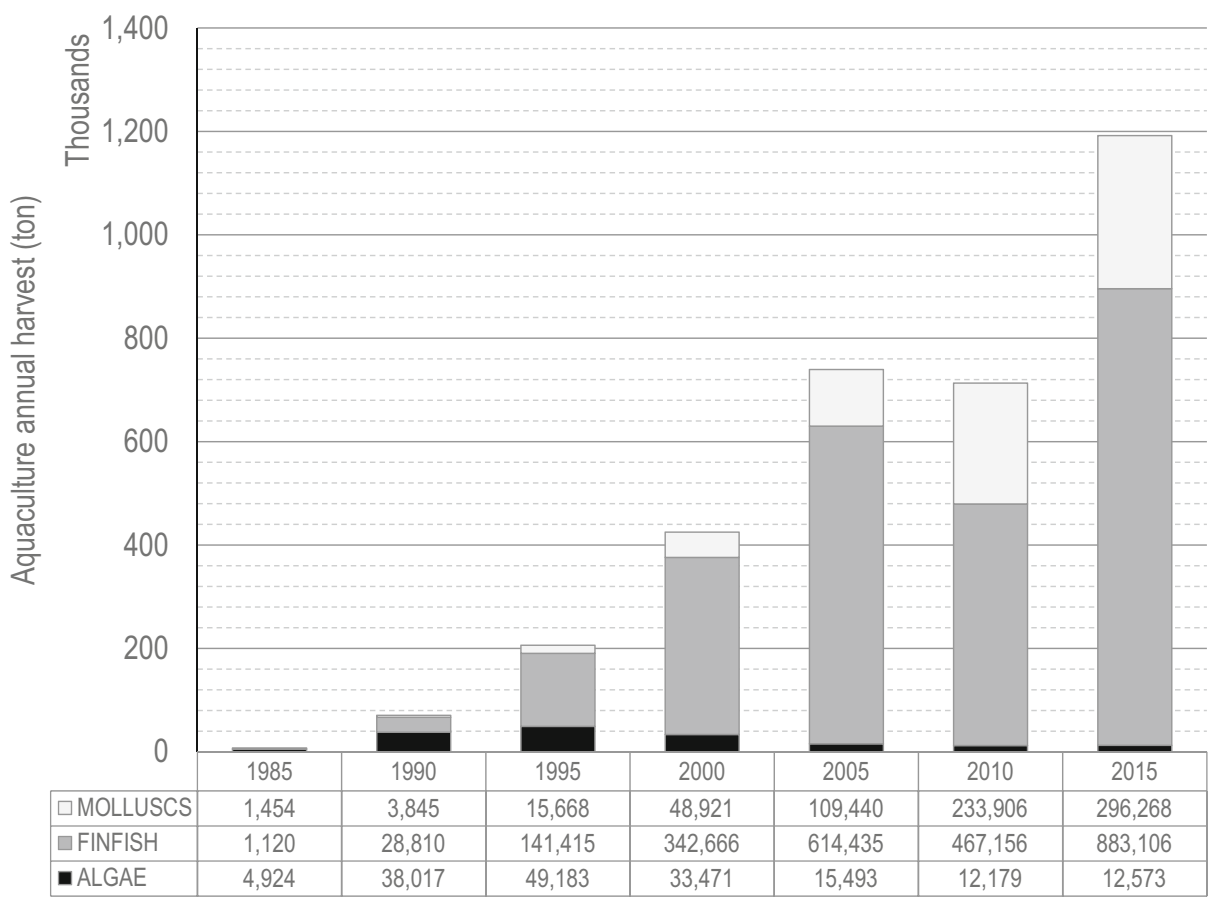

Fig. 1 Evolution of Chilean aquaculture between 1985 and 2015 (source: Chilean National Fisheries Service Statistics, 1985-2015)

Chile has developed a successful export-oriented aquaculture industry, which has been able to take advantage of high consumer demand in three of the largest trade markets in the worldJapan, the USA and the EU accounting for 4497 million USD FOB in 2014 (Fig. 4). Figure 5 shows the relative importance of Chilean aquaculture exports by country of destination and

Export Value FOB

(4,497 Million USD 2014)

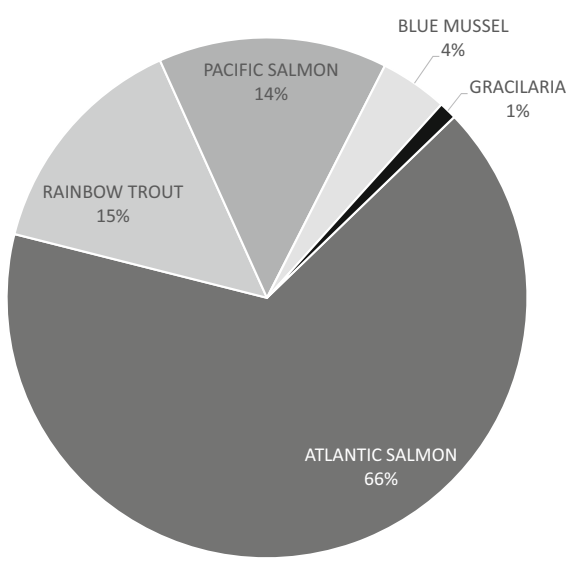

Export Volume (625,845 ton)

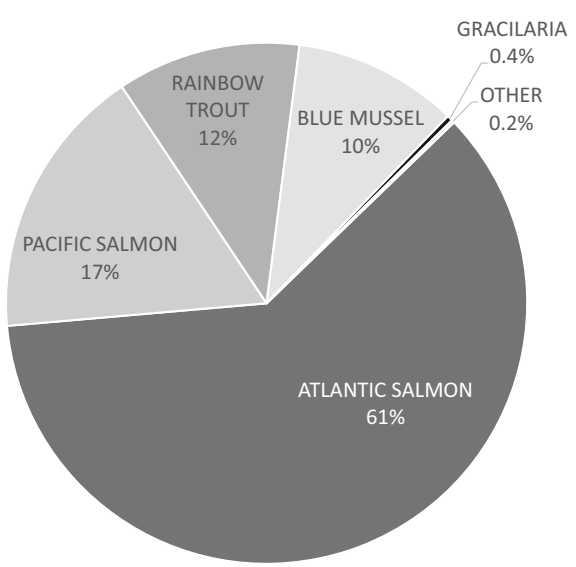

Fig. 2 Chilean aquaculture exports in 2014, by specie in value (USD FOB) and volume (on) (source: Chilean Customs Service statistics 2014) 


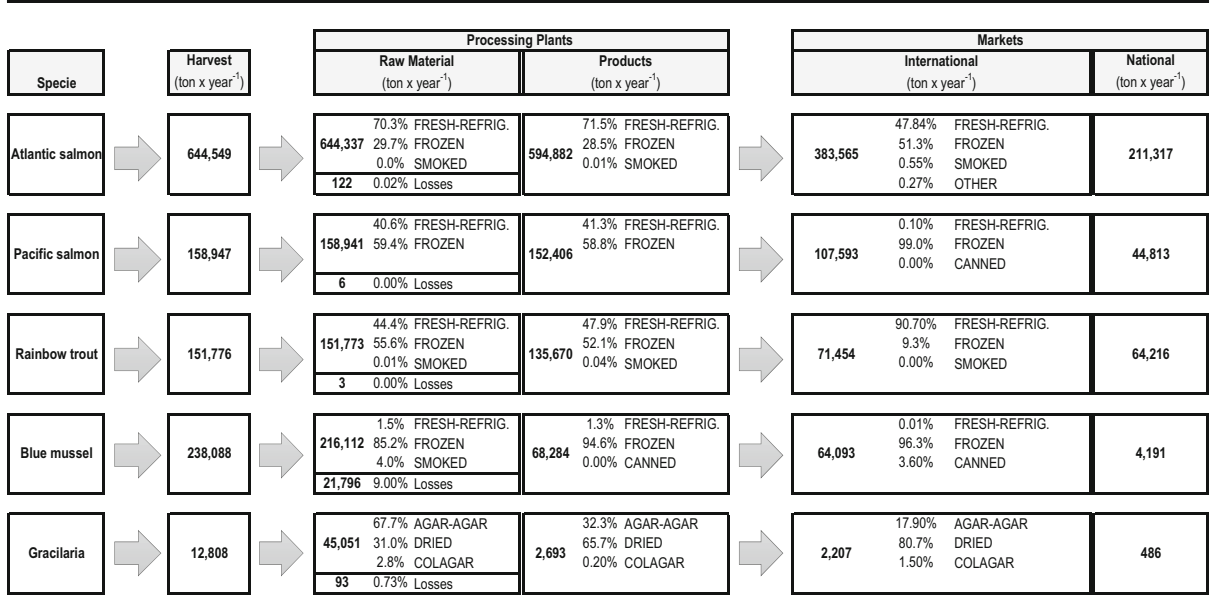

Fig. 3 Trade flow of main Chilean aquaculture species in 2014, volume (tonnes) (source: Chilean National Fisheries Service statistics, 2014 and Chilean Customs Service statistics, 2014)

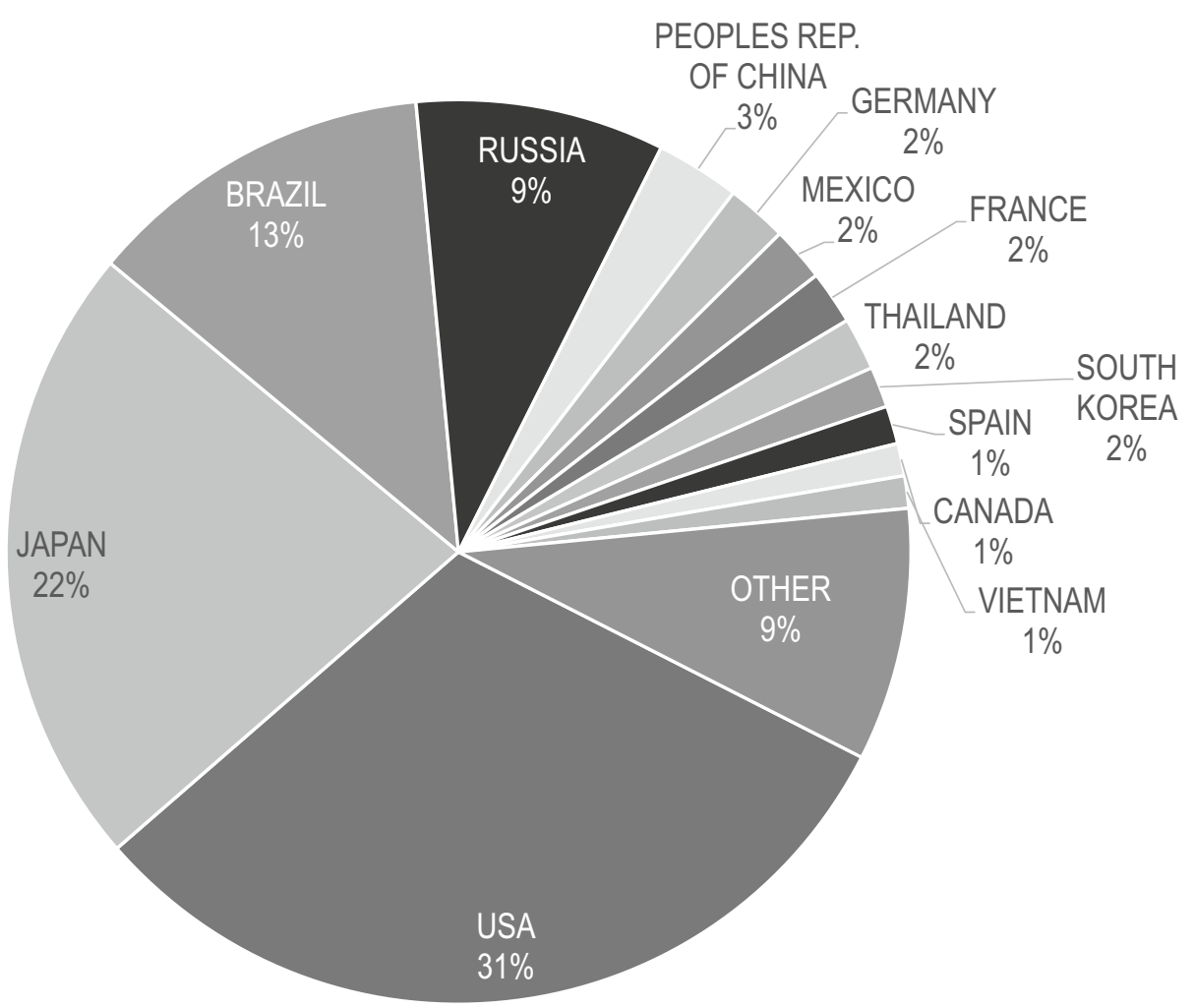

Fig. 4 Chilean aquaculture exports in value terms, by country of destination 2014 (source: Chilean Customs Service statistics 2014) 


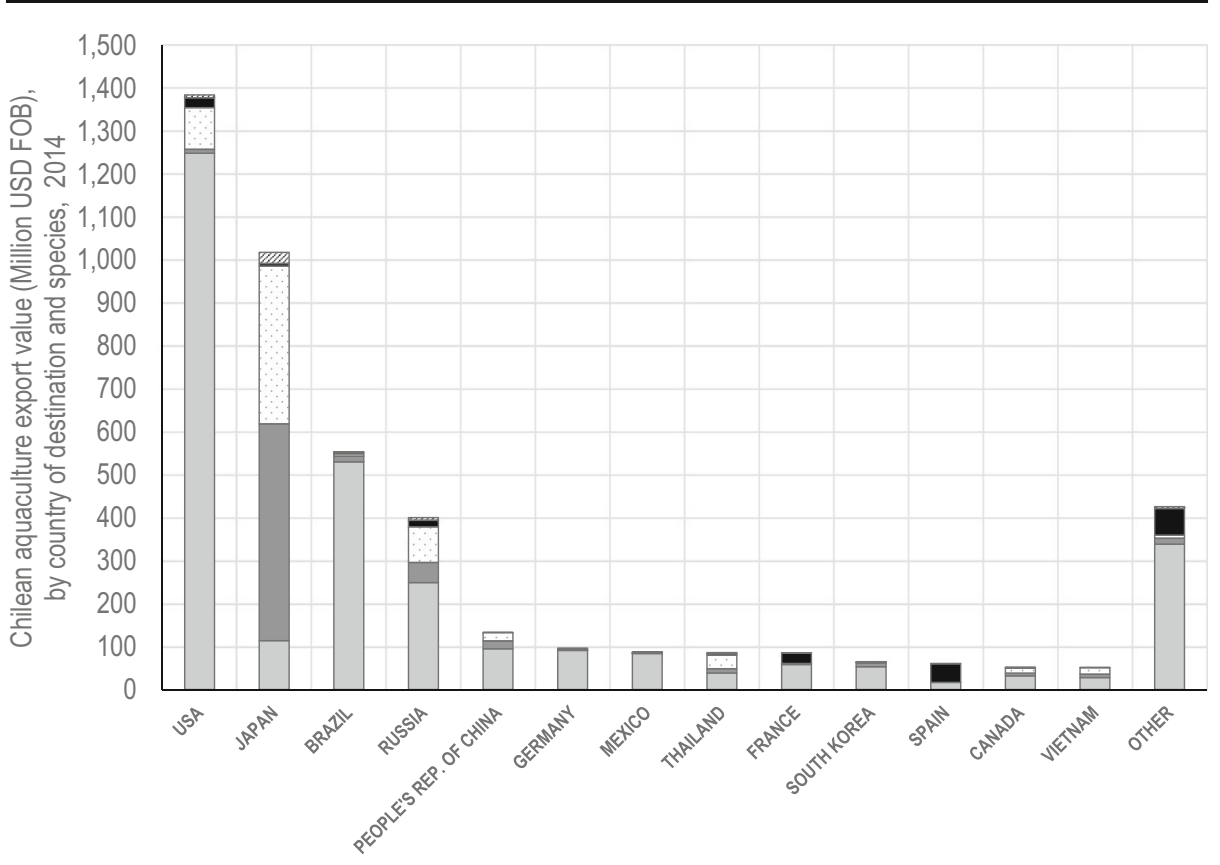

\section{$\square$ ATLANTIC SALMON $\square$ PACIFIC SALMON $\square$ RAINBOW TROUT $\square$ BLUE MUSSEL 四RACILARIA}

Fig. 5 Relative importance of the main international markets for Chilean aquaculture products 2014, by value in USD 2014 (source: Chilean Customs Service statistics 2014)

species exported, including salmonids, blue mussel and seaweed. The production of salmon, trout and mussel takes precedence for several reasons. First, these species are demanded in the high-income export markets; second, relevant farming factors including water quality are well suited to produce these species and; third, Chile is geographically close to the main fishmeal and oil production centres, which is still important given that fishmeal and oil provide the main ingredients in feed for salmon species.

Farmed salmon production is dominated by large multi-national companies, with some of the major global operators having large operations in Chile (e.g. Marine Harvest and the Cermaq Group). Around 70\% of the world's salmon production is farmed. Farming takes place in large nets (cages) in sheltered waters, such as fjords, lochs or bays. There are few countries with coastlines suitable for farming salmon, and therefore, the majority of the world's production comes from Norway, Canada, Chile and the UK. Varieties of salmon have become a very popular food, consumed in both traditional markets, such as the USA, the EU and Japan and also in new emerging markets, e.g. Asia. The health benefits of consuming salmon, because of its high content of protein and omega 3 fatty acids, as well as being a good source of vitamins and minerals, have contributed to increased demand.

\section{Development in Atlantic salmon production}

Norway, who pioneered the farming of Atlantic salmon in the 1980s, remains the world's largest producer accounting for $63 \%$ of the global farmed production volume of around 2.3 million tonnes in 2016 (FAO 2018). Farmed salmon is now a global commodity traded throughout the world, representing the most important product in Chilean aquaculture (by 
value). Until 2006, Chile had experienced over 15 years of growth and was expected to become the world's largest producer of Atlantic salmon. However, since 2006, the industry has faced several setbacks, allowing Norway to retain its dominance in the world market for farmed Atlantic salmon. The most significant setback was the outbreak of infectious salmon anaemia (ISA). This, along with record levels of antibiotic use, which peaked in 2015 at $557 \mathrm{t}$, to treat virulent and pervasive bacteria, has been reported to drive away some USA retailers from Chilean salmon (Bailey 2014). However, following several years of persistent increases in antibiotic use, 2016 saw a significant decline to $382 \mathrm{t}$ (Lozano et al. 2018). As shown in Fig. 4, Chile's most important export market for aquaculture products are the USA, Japan, Brazil, Russia, China and the EU.

Furthermore, harmful algal blooms are the most recent of the setbacks affecting the industry. Higher than usual sea temperatures and declining precipitation, especially during the summer, have caused algal blooms (Leon-Munoz et al. 2018). In 2016, government and industry estimated that the impact of algal blooms accounted for the loss of 100,000 t of salmon, with a retail value of USD 800 million, impacting 35 of the 415 salmon farms - see, e.g. Leon-Munoz et al. (2018).

In terms of global production, Chile accounts for $13 \%$ (down from $38 \%$ in 2006), the UK $10 \%$ and Canada $7 \%$, thus four countries (including Norway) account for $93 \%$ of production by volume. The remaining $7 \%$ is accounted for by countries including Australia, Ireland and the Faroe Islands. Chile is, however, increasing market share in total salmon production - for example, over $95 \%$ of farmed Coho salmon is undertaken in Chile and mainly consumed (over $90 \%$ by volume) in Japan.

Of the other major producing countries excluding Norway, Chile has seen the most growth. From a production of zero in the early 1980s, by 1992, Chile had surpassed both Canada and the UK. Since the early 1990s, Chile has maintained its position in the market for farmed salmon (despite significant decreases in output since 2006). According to Chilean official statistics, production of Atlantic salmon in 2016 was approximately 800,000 t, contributing to the worldwide production of around 2 million tonnes, with a first sales value of approximately USD 4.5 billion. All of the production of Atlantic salmon is processed, with around $2 / 3$ offered as fresh, with the rest offered as frozen - this is largely a result of the demands of export markets. As shown in Fig. 3, there is some processing into canned/smoked fish, although this is less than $1 \%$ of total production.

It is expected that the Chilean Atlantic salmon industry would have surpassed production from Norway if the necessary infrastructure was in place, and if geographically Chile was closer to the main European markets. Further, and perhaps most importantly, Chilean salmon would have increased output at a quicker rate had research and government and regulation kept pace with the rapid increase in output (which may have resulted in lesser impacts of the setbacks faced by the industry). Industry expansion (in general) is correlated with negative impacts, both locally and globally. The salmon farming industry has been no different and a number of studies have discussed the environmental impacts including disease, interaction with wild populations, pollution, feed use etc. (see, e.g. Naylor et al. 2000, 2009; Wang et al. 2012; Taranger et al. 2015). Aside from the major disease incidents that have halted production in the main producing countries, environmental sustainability is a key concern regarding further expansion. Most notably, the limited supply of fishmeal and oil may pose a biological limit on production if substitute goods are not available or found to be economically efficient. While the use of fishmeal in diets for Atlantic salmon has decreased in recent years due to economic and 
sustainability concerns, there are limited studies that demonstrate the technical and economic viability of fishmeal free diets beyond short term experimental conditions (see, e.g. Davidson et al. 2016).

The next section considers the production and market constraints and their potential impact on a further expansion of Chilean salmon farming industry.

\section{Production and trade opportunities and constraints}

It is well documented that productivity growth is the main driver in the increased output of farmed salmon, as innovations that lead to productivity growth also improve the competitiveness of salmon producers (Asche 2008). In Chile, output of Atlantic salmon had seen several years of growth until the first major setback following disease outbreak in 2006-7. This was followed by several years of reduced growth and declining market share for Chilean farmed Atlantic salmon. Further disease problems in 2010-2011 caused a global crash in the market price for farmed Atlantic salmon, followed by recent growth in Chile outpacing that of the Norwegian industry (although this is expected to be reversed in the short term as a result of stricter regulatory controls on production growth in Chile - see section on trade regulations).

While most of the focus has been on productivity growth at farm level, as noted out by Asche et al. (2009a, b), other sources that explain growth in the salmon industry are also important. Tveterås and Heshmati (2002) note that about two thirds of the productivity in Norwegian salmon farming is due to improved input factors. Cost and availability of feed (as discussed in this paper) is the most important input factor (by cost share), and although it is decreasing, as alterative ingredient use in feeds is increasing, it remains the most important input factor share by cost. As noted by Guttormsen (2002), in the short term, feed cost may be referred to as the only variable input factor.

Tighter regulation on environmental control (see section on trade regulations) has largely been implemented in response to curtail production levels, specifically stocking densities, which are known to correlate with disease outbreak and spread. Other innovations as noted by Asche et al. (2013), e.g. contract sales, logistics and marketing, are possible only because of salmon producers having become larger. Compared with other major producing countries, Chile has seen a similar transformation to Norway, with respect to the number of producers becoming concentrated and farm size increasing (companies engaged in Chilean aquaculture has decreased by two thirds since the late 1990s, although production has increased).

The externalities of salmon farming are well documented (see, e.g. Asche et al., 2009a, b; Naylor et al. 2000, 2009; Olesen et al. 2011; Taranger et al. 2015). In particular, salmon farming has been marred with environmental concerns, ranging both input factors (i.e. cost and availability of feed) to output factors including pollution (e.g. nutrient loading) and interaction with wild stocks (transmission of disease, interaction of escaped farm fish with wild populations, e.g. genetics). Further, salmon farming is indirectly impacted through climate variability (e.g. rising sea temperatures and fluctuating anchoveta catches for fishmeal production) and limited space availability for further expansion. The environmental impacts of salmon farming are varied and interactions between different actors (e.g. chemical and antibiotic use impacting on wild populations, escapees interacting and competing with wild populations, impact on benthic fauna from nutrient loading), may produce complex changes in coastal ecosystems (Buschmann et al. 2009). It is also recognised (see Buschmann et al. 2006) that the environmental impacts of salmon farms can affect marine food webs through attracting carnivorous 
birds and mammals. While Chilean regulation relevant to salmon farming recognises these issues, the impacts of these unintended outcomes remain largely unquantified.

Integrated Multi Trophic Aquaculture (IMTA) has gained support as a potential production system to mitigate the environmental concerns of salmon farming. IMTA was first trialled in Chile in the 1980s to produce rainbow trout. Evidence suggests that IMTA is technically feasible for a number of species, and outputs that would have otherwise be categorised as a negative externality in traditional salmon net pen farming, can be utilised in other production processes (e.g. the fouled waters from rainbow trout IMTA in Chile were used to cultivate oysters and algar-producing alga Gracilaria (Buschmann et al. 1994). However, while such technologies may be technically feasible, economic viability needs to be demonstrated if they are to be adopted on a commercial scale. For salmon, no such studies have demonstrated the economic viability of IMTA, and as such, it is not commonplace in salmon aquaculture.

The following section details the most recent and significant production constraints faced by the industry (i.e. cost/availability of feed and disease control). The discussion is informed by interviews with industry actors, conducted as part of the Aquaculture for Food Security, Poverty Alleviation and Economic Growth (AFSPAN) in 2015. This is supplemented by the growing amount of literature on the negative externalities of salmon farming.

\section{Cost and availability of feed}

The food used in intensive aquaculture is of particular importance with regard to the technical and economic aspects of production, serving to assure the quality and security of aquaculture's products, control over costs of production and control of the impact of aquaculture on the surrounding environment. Fishmeal and oil are primarily used in carnivorous fish culture as it enables farmed fish to retain the same nutritional properties as wild caught fish. This is particularly important regarding the marketability of salmon and the health benefits promoted through eating fish high in omega 3 (and the use of fishmeal and oil promotes this for the production of farmed Atlantic salmon). However, production of fishmeal and oil relies mainly on captures from industrial fisheries, with South America being the world's largest producer of these commodities. Ytrestøyl et al. (2015) found that while the use of fishmeal has declined in salmon feeds in the last decade, this had a minimal impact on the total use of fishmeal, as production of salmon species has increased significantly to meet global market demand in the last decade. Given the limited supply of fishmeal and oil (more than $30 \%$ of global production being derived from one species - the Peruvian anchoveta) and the rapid growth of aquaculture (in general) since the 1980 s, research into the substitutability of fishmeal and oil began around two decades ago. The research is still ongoing and is in line with the summary provided in the latest 2018 FAO State of World Fisheries and Aquaculture overview, which reports that the proportion of landings directed for fishmeal/oil production has shown a downward trend in the last decade, because of reduced catches of anchoveta. However, owing to the growing demand from aquaculture for fishmeal and fish oil, coupled with high prices, a growing share of fishmeal is now being produced from by-products, which previously were often wasted. The reliance on fishmeal and oil in diets, therefore, represents a concern-given production from industrial fisheries falls into the FAO's classification of over-exploited fisheries. While several studies (see, e.g. Davidson et al. 2016; Pratoomyot et al. 2011; Salze et al. 2010; Sealey and Hardy 2011; Tacon and Metian 2008; Ytrestøyl et al. 2015) have reported that the substitution (at varying levels) of fishmeal is technically feasible, this is only half the story. Further research is required regarding the economic viability of fishmeal free diets. 
Aquaculture, in particular the production of high value carnivorous species, are the largest net consumers of fishmeal globally and have remained so, even though the current price (November, 2018) of fishmeal is now around US\$ 1500 per tonne (Intrafish 2018), and it has been as high this year (January, 2018) as US\$ 1800 per tonne (price fluctuation largely due to fluctuations in anchoveta landings). This indicates the perceived economic necessity of utilising fishmeal in feeds for species like salmon. It further suggests that fishmeal will no longer be a readily useable commodity in the long term, as falling supply and rising demand is forcing it to become a strategic ingredient to maximise falling economic returns, as noted by Drakeford and Pascoe (2008). However, the demand for fishmeal shows little sign of declining - rather the last decade has required fishmeal producers to utilise alternative sources, e.g. waste fish, resulting from the decline in the anchoveta production of fishmeal.

Furthermore, the use of alternative ingredients in fish feed, particularly, but not limited to the production of salmon species, is not without concern. Soybean meal, an ingredient of much focus for substituting fishmeal, is considerably cheaper at around US\$ 300 per tonne (Intrafish 2018). However, the current trade war between the USA and China (at the time of writing this paper) is expected to increase the price of soybean meal, as China's reciprocal levies on USA agricultural products come into force.

The FAO (2018) also report that the use of fishmeal in diets for species that have no requirement for fishmeal (e.g. omnivorous species like carp) and agricultural sectors (mainly pig production) is still common place to increase productivity. This supports the research of Drakeford and Pascoe (2008), published over a decade ago, and suggests it remains valid, i.e. while it may be technically feasible to substitute fishmeal and oil in diets for salmon, it may not be economically viable (or even desirable, e.g. the marketability of salmon fed feeds high in omega 3 fatty acids).

\section{Disease control}

The impressive growth in Chilean salmon output has not been accompanied by the levels of research, monitoring and regulatory advances seen in Norway throughout the development and expansion phase of the industry. This lack of research, monitoring and regulation first became apparent in the industries response to the control of the outbreak of ISA in 2006. The three primary fish diseases in the Chilean industry prior to 2007 were parasitism caused by Caligus sea lice (Caligus rogercresseyi), salmonid rickettsial septicaemia (SRS) caused by Piscirickettsia salmonis, and infectious pancreatic necrosis (IPN), caused by the pancreatic necrosis virus (IPNV). The negative impact of these diseases on production was compensated by increasing smolt numbers in salt-water cages. SRS, the most significant disease, does not have an effective vaccine, but is treatable; and is largely responsible for the high levels of antibiotic use.

Recently, ISA has been responsible for the most significant losses (in economic terms) to the salmon farming industry worldwide, particularly through damage caused to export markets, customer perception and other social impacts (Bailey 2014). The first ISA outbreak was in Norway in the early 1980s, followed by Canada, Scotland and the Faeroe Islands in the 1990s. In fact, ISA outbreaks have been associated with all major producing countries. In Chile, the disease control measures implemented due to ISA crisis have also apparently decreased the number of SRS cases in the industry (Alvial et al. 2012). 
While it was proposed that production levels would again reach and exceed pre-2006 levels by 2013-2015, after recovering in 2011 onwards, Chile has faced other significant challenges to increasing production. These have come about even though there is now improved governance and management, including a new regulatory framework, which has facilitated the industry's recovery. These include biosecurity, climate variability and competition for space.

Most local environmental impacts of salmon farming are attributed to the high density of sites (geographically close) and the high density of production. Farms are seeing increased losses because of over-production and rising costs related to disease prevention and cure (Bailey 2014). As noted by Buschmann et al. (2009), there is a need for increased levels of research into the impacts of salmon farming specifically in the Chilean context, which currently remains largely unstudied. This is required to develop a further improved regulatory framework of science-based evidence. Further, as noted by Asche et al. (2018), there is a global market for salmon with a common price determination process. Therefore, the reduction in supply from Chile (e.g. disease crises) benefits all other producers with higher prices.

The following section considers the role of trade and markets on farmed salmon production in Chile.

\section{Trade regulations}

While the demand for aquaculture products continues to increase, there is a growing recognition of quality and safety of products by consumers. These include food safety, traceability and eco-labelling, which are considered a high priority by the main retailers in global markets (e.g. supermarkets, restaurants). There has been an upward trend in the export of fish products since the early 1990s, due in part to globalisation and favourable trade liberalisation policies (fish products are not subject to the same tariffs in many markets as agricultural products are, e.g. the EU). Further, technological innovations, including improved processing to meet market demands and changes in distribution and marketing, have changed the way in which fish products are delivered to consumers (through the aquaculture value chain). Atlantic salmon are among the top ten exports of fish products, with Chilean salmon rising to number eight of the top ten exports by 2008. This resulted from increased demand in Chile's main export markets, but also because of new and emerging markets (in developed and emerging economies).

In order to gain wider access to export markets, through the main channels of modern retail and supermarkets, markets are demanding increasingly detailed requirements on ethical and environmental criteria. At the global level, there have been four significant developments in the area of aquaculture relevant to Chilean salmon farming. The FAO's international guidelines on aquaculture certification and the WWF's development of global standards for the responsible aquaculture of 12 species, including salmon, where socially responsible aquaculture is high on the agenda. Furthermore, the Global Aquaculture Alliance (GAA), which promotes responsible aquaculture practice through education, advocacy and demonstration to deliver environmentally and socially responsible aquaculture. In addition, the Best Aquaculture Practices (BAP) administered by the GAA coordinates the development of certification standards for processing plants, farms, hatcheries and feed producers.

Currently in Chile, there are six regulatory programmes that are mandatory to produce and trade aquaculture products in Chile, most of them specifically directed to export products, 
processing and trade. Four of these programmes are aimed at product quality and safety issues and only one to safety and another to environmental quality (see Table 1).

In addition, Table 1 presents seven international voluntary eco-label systems that are applied to aquaculture in Chile. All of the voluntary mechanisms are concerned with product quality issues; five are concerned with environmental issues, three with social issues and two with product safety issues. A brief description of each of the mandatory regulations is presented in Table 1-and the extent to which they act as drivers in the aquaculture chain in Chile is summarised as follows:

Quality Assurance Programme (PAC) This programme applies the Hazard Analysis and Critical Control Points (HACCP) methodology to the production process. The industry HACCP plans are approved and overseen by the Chilean National Fisheries Service, based on the EU Codex Alimentarius.

Certification Programme (CER) Necessary procedures to export fishery products and to request sanitary and origin certifications.

\section{Control Programme for Pharmaceutical Residues, Pollutants and Forbidden Substances}

(FAR) This programme establishes the control procedures followed by the Chilean National Fisheries Services, with respect to pharmaceutical residues, pollutants and forbidden substances, the purpose being to guarantee the safety of aquaculture products. This programme complies with the EU Community Directive 96/23/CE.

Sanitary Programme for Bivalve Molluscs (PSMB) To guarantee the sanitary quality of bivalve molluscs directed to exports through categorisation and monitoring of the areas of grow-out and harvest. Chilean PSMB is based upon regulations included in the National Shellfish Sanitation Programmes for both EU and USA-FDA.

Enabling Programme for Fish Processing Plants, Fishing Vessels and Fishing Factory Vessels (HPB) Categorises the premises and the sanitary management for fish processing plants, fishing vessels and fishing factory vessels under the good manufacturing practices (GMP) regulations from the USA.

Programme for the Traceability of Fishery Products (TPP) This programme sets the general guidelines for the establishment of traceability systems on fish processing plants producing for the international markets.

\section{Impact of trade regulations}

The regulatory framework in Chile has been perceived to be weak (see, e.g. Buschmann et al. 2009; Taranger et al. 2015; Wang et al. 2012) relative to other producers, e.g. Norway and Scotland. ${ }^{4}$ As described by Tecklin (2016), the previous laissez faire approach to regulating the Chilean salmon industry has, since 2009 , been replaced by more stringent government

\footnotetext{
${ }^{4}$ However, as noted by Osmundsen et al. (2017), there are challenges with the regulatory system in other countries. 


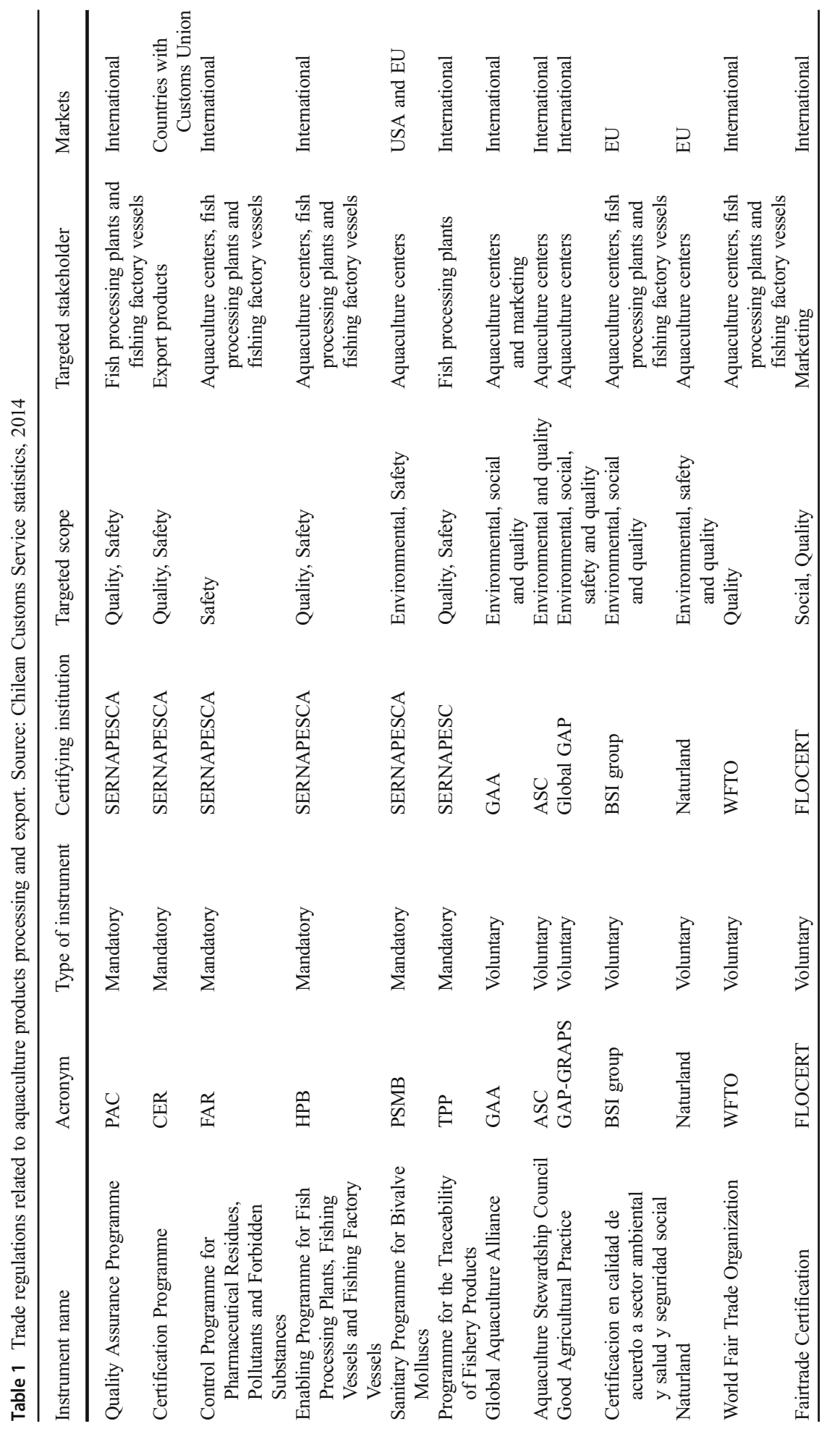


regulations. As markets become more demanding on environmental standards, producers have reacted to become compliant with certification schemes.

Industry organisations have been vocal in lobbying for stricter regulation to reduce the risk of further disease outbreaks and to grow production sustainably. The role of industry in achieving these objectives determines the extent to which their products are demanded in international markets, relative to substitute products, i.e. farmed salmon from other countries. Specifically, the extent to which disease is controlled (and the use of chemicals and antibiotics minimised) is critical to Chile maintaining a strong market position for Atlantic salmon. Overcoming the disease problems from 2006 onwards has led to reduced production from Chile for several years. Now, output from Chile (since 2015) has seen higher growth rates than Norway, leading to positive impacts on Chilean salmon market share, as the industry was able to take advantage of current high prices. Better regulation can be attributed to this.

Although the recent density regulation has received a mixed reception by industry (full discussion of this directive in the following section), as some fear that other countries will be able to increase production to fill the gap in the market, as prices for farmed salmon remain high, other regulations have generally been supported by industry. Most of the developments in the regulatory framework have been well received. Regulations on licencing for new operations has improved, with greater distance between farms (partly to prevent transmission of disease between farms) but also to protect areas that are important for the ecosystem services they provide, e.g. migrating whales and birds. The Chilean industry recognise that further sustainable expansion relies on improving the environmental reputation of farmed salmon. Chile are a member of the Global Salmon Initiative (GSI). The GSI members are committed to improved sustainability through cooperation and transparency. The aim is to achieve standards for all Chilean suppliers, so they can achieve certification from the Aquaculture Stewardship Council (ASC), which has progressed since 2014 when Cermaq (one of the main producers in Chile) achieved ASC status.

\section{Market constraints and opportunities}

Salmon's share in world fishery trade has increased strongly in recent decades. This is largely due to increased aquaculture production of salmon and trout from northern Europe and in North and South America (FAO 2018). Demand has grown steadily in the main markets for farmed salmon, particularly through new processing varieties. However, Brækkan et al. (2018) note that more than $50 \%$ of the demand growth for salmon in the main markets is in essence a 'black box' of unknowns, contributing to a large variation in demand growth between the years. Since the market price crash in 2011, prices have risen strongly, and as discussed in the previous section, the Government's Density Directive supports sustained growth in output to maintain and grow Chile's share in the main markets.

The market price for salmon is, however, determined by several factors. These include the variations in supply and the coordination among the main salmon producers, as well as seasonal variations, which also affects demand. As salmon farming has increased, the market has expanded in geographical as well as product space (Asche and Bjørndal 2011). Additionally, the global market within which Chilean producers compete, and the arbitrage

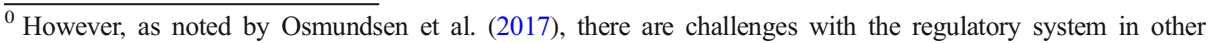
countries.
} 
opportunities between regional markets, impacts on market prices (see, e.g. FAO 2019). Following 2011, prices began to steadily increase, with slight increases and decreases witnessed in 2013 as a result of changing demand patterns. Year 2016 saw historic high prices for farmed salmon, but indications are that prices may be 30\% lower in early 2019 (FAO 2018) due to overproduction in Chile (5\% higher than 2016) and Norway (10\% higher than 2016). Further complexities include the presence of sales contracts, which reduces the quantity available for the spot markets, along with flexibilities of market channels and the fact that many markets are price-sensitive.

The Chilean industry has, in recent years, been moving through an important transformation process, partly in response to the world economic crisis and also addressing the higher production costs in the Chilean industry resulting from tighter production regulations. Higher costs feeding down the value chain, e.g. fishmeal in artificial feeds (see, e.g. Davidson et al. 2016) is also affecting the industry.

However, output growth is expected to decline from 2019 in response to the Governments proposed biomass cap - the density directive. The density directive is designed to slow down output growth and to try to de-incentivise over-production decisions (currently related to higher than normal market prices) that create "boom-bust" economic cycles in the industry. This has been seen as positive by some producers, especially in relation to the recently reported case of ISA - one of the drivers behind the proposal (as higher stocking densities are directly link to the development and spread of ISA). However, the opposing view is that the density directive will leave a gap in the market (exacerbated by higher market prices) that will be filled elsewhere.

\section{How market constraints are perceived by industry?}

The information presented in this section is based upon interviews carried out as part of the AFSPAN Project (AFSPAN 2015). The interviews were all conducted with Atlantic salmon producers.

With respect to market constraints and how they are perceived by aquaculture producers, it was noted that salmon producers are all large producers and their companies entered the business seeking to diversify their investment portfolio, from other companies in the fisheries sector. The main driver was to increase capital, wealth and company value. Salmon producers chose the species based on market information related to volume and price and their profit expectations as Atlantic salmon exhibits the highest growth rate for natural resource allocation. Production levels in the beginning were defined by the need to increase market share, and in search of economies of scale. Presently, producers are more concerned with profitability, based on a balance between volume, cost and price. The product quality standard is set by the markets and in general is related to product size, colour and shelf life. The Asian market, mostly Japan, is also concerned with presentation, and the USA with food safety issues.

Regarding innovating on species, technology and/or products, salmon producers report that there have been innovations at farm level to improve efficiency and profits, and in some cases possibilities of innovating on new types of products, so small/medium traders are differentiated in markets. They also report that in general, salmon are also sold in the international market as a commodity to large traders, thus leaving little room for adding value from the supply side.

Of the Salmon producers interviewed, who all directly export, whether they are vertically integrated with a processing plant or not, report they perceive consumer preferences through large import traders (wholesalers and/or large supermarket chains), and use this as a strategy to 
minimise risk. It was also suggested that the market works through a pull strategy, where the demand side drives change.

With regard to acting on market signals, there was suggestion that salmon farmers, as commodity exporters, are largely interested in volume as opposed to added value. Furthermore, interviewees suggested that monitoring market conditions and being in a position to be able to react is one of their primary concerns. For example, it is important to monitor the Norwegian market, particularly to detect excess production and react accordingly.

It was also reported that changes in species, production technology and products are dictated by market changes, only when cost issues allow for this (for example, the recent adoption of copper alloy nets in the Atlantic salmon grow-out period). The use of this new technology is expected to reduce mortality through the reduction of fouling, stress from management - and avoidance of net pen water volume shrinkage due to currents. All this could mean a reduction in the use of antibiotics and better compliance with market regulations.

The formation of the Global Salmon Initiative, implemented by industry since 2012, was initiated on a fundamental principle, "Those producers quickly realized that when one company performs poorly, it harms the reputation of all, and instead of using environmental performance as a means of competition, they would secure greater advantages and economic success by working together to lift the performance of the sector as a whole" (Global Salmon Initiative 2018).

The GSI members now account for over $70 \%$ of global farmed salmon production and industry recognise the fundamentals of a regulatory environment that is conducive to a further sustainable increase in output. Chile has made significant advances in implementing regulations to support this, recognising that as consumers become more demanding of environmental concerns they need to interpret market signals (from consumers) and address environmental concerns, collectively as global salmon producers. The GSI has been credited as a significant step in this regard.

\section{Conclusion}

Aquaculture has grown rapidly in Chile in the last couple of decades. In particular, the production of farmed Atlantic salmon has seen impressive growth as an export-orientated industry, contributing to employment and economic growth. Atlantic salmon represents the most important species by volume and value. As well as exporting to the main markets, i.e. the USA, the EU and Japan, Chile has increased its share in new markets, e.g. Asia.

The first major setback in Atlantic salmon production in Chile was in 2006-2007. It is noted that growth to this point had outpaced research and development and government policy, particularly the development of a regulatory framework governing the sustainable expansion of the sector. The industry has been blighted by environmental and disease problems - most significantly the ISA outbreak in 2006-2007 and the recent algal blooms caused by the El Nino phenomenon in 2016. Trade and market impacts need to be better addressed, by both government and industry. The Chilean industry has made significant progress in this regard. Most producers are members of the Global Salmon Initiative - a global industry drive for achieving sustainable production. Further, some producers have also achieved the Aquaculture Stewardship Council accreditation.

The government and aquaculture regulator in Chile (Sernapesca) have made significant strides forward with regards to developing a regulatory framework that is conducive to a further sustained increase in output. For example, the current Density Directive addresses minimising risks associated with further disease outbreaks (through controlling farm location and stocking density), and also controlling output to prevent overproduction. This is designed 
to assist the industry in mitigating some of the market and trade issues discussed in this paper and through better regulation to address these issues, a further sustainable expansion in the Chilean salmon farming industry may result.

Further, development in the regulatory framework may lead to increased investment in infrastructure and investment by industry improving the potential for further increases in aquaculture output. One key constraint that is currently not addressed, including recent advances on regulation, is the use of feeds with no limits on the amount of fishmeal that may be utilised. While the industry (and feed manufacturers) have made significant gains in reducing the amount of fishmeal required in feeds (largely through partial substitution and increased feed efficiency), the overall demand for fishmeal has increased in line with increases in production (as well as continued use by producers of species, e.g. carp where there is no direct requirement and other sectors, e.g. agriculture). This is supported by the high market price for fishmeal, which although has fluctuated in recent times, is significantly higher than a decade ago, when Drakeford and Pascoe (2008) suggested that fishmeal may provide an input control to further industry expansion.

Funding information Financial support was provided by the EU 7th Framework Programme Project: Aquaculture for Food Security, Poverty Alleviation and Nutrition (AFSPAN) for the completion of this article. Any errors or views expressed in this article are solely the responsibility of the authors.

\section{Compliance with ethical standards}

Conflict of interest The authors declare that they have no conflict of interest.

Ethical approval The article does not contain any studies with animals performed by any of the authors.

Open Access This article is distributed under the terms of the Creative Commons Attribution 4.0 International License (http://creativecommons.org/licenses/by/4.0/), which permits unrestricted use, distribution, and reproduction in any medium, provided you give appropriate credit to the original author(s) and the source, provide a link to the Creative Commons license, and indicate if changes were made.

\section{References}

AFSPAN (2015) Aquaculture for food security, poverty alleviation and nutrition. Final technical report. FAO, fisheries and aquaculture division, Rome $58 \mathrm{pp}$

Allison EH (2011) Aquaculture, fisheries, poverty and food security. Working Paper 2011-65. WorldFish Center, Penang, p 62

Alvial A, Kibenge F, Forster J, Burgos JM, Ibarra R et al (2012) The recovery of the Chilean Salmon industry: the ISA crisis and its consequences and lessons. The global aquaculture Alliance, St. Louis, p 83

Asche F (2008) Farming the sea. Mar Resour Econ 23(4):527-547

Asche F, Bjørndal T (2011) The economics of Salmon aquaculture. Management, 2nd edn. Wiley-Blackwell, London

Asche F, Hansen H, Tveterås R, Tveterås S (2009a) The salmon disease crisis in Chile. Mar Resour Econ 24(4): 405-411

Asche F, Roll KH, Tveteras R (2009b) Economic inefficiency and environmental impact: an application to aquaculture production. J Environ Econ Manag 58:93-105

Asche F, Roll KH, Sandvold HN, Sørvig A, Zhang D (2013) Salmon aquaculture: larger companies and increased production. Aquac Econ Manag 17(3):322-339

Asche F, Bellemare M, Roheim C, Smith MD, Tveteras S (2015) Fair enough? Food security and the international seafood trade. World Dev 67:151-160

Asche F, Cojocaru A, Sikveland M (2018) Market shocks in salmon aquaculture: the impact of the Chilean disease crisis. J Agric Appl Econ 50(2):1-15 
Bailey J (2014) Looking for sustainable solutions in salmon aquaculture. Etikk I Praksis - Nord J AppL Ethics $8(1): 22-40$

Bene C, Arthur R, Norbury H, Allison E, Beveridge M et al (2016) Contribution of fisheries and aquaculture to food security and poverty reduction: assessing the current evidence. World Dev 79:177-196

Beveridge M, Thilsted S, Phillips M, Metian M, Troell M, Hall SJ (2013) Meeting the food and nutrition needs of the poor: the role of fish and opportunities and challenges emerging from the rise of aquaculture. J Fish Biol 83(4):1067-1084

Brækkan EH, Thyholdt SB, Asche F, Myrland Ø (2018) The demands they are a-changin'. Eur Rev Agric Econ 45(4):531-552

Buschmann AH, Mora O, Gomez P, Bottger M, Buitano S et al (1994) Gracilaria chilensis outdoor tank cultivation in Chile: use of land-based salmon culture effluents. Aquac Eng 13:283-300

Buschmann A, Riquelme V, Hernandez Gonzalez M, Varela D, Jimenez J et al (2006) A review of the impacts of salmonid farming on marine coastal ecosystems in the Southeast Pacific. ICES J Mar Sci 63:1338-1345

Buschmann H, Cabello F, Young K, Daniel V, A \& J, Henriquez L (2009) Salmon aquaculture and coastal ecosystem health in Chile: Analysis of regulations, environmental impacts and bioremediation systems. Ocean Coast Zone Manag 52(5):243-249

Ceballos A, Dresdner-Cid JD, Quiroga-Suazo MÁ (2018) Does the location of salmon farms contribute to the reduction of poverty in remote coastal areas? An impact assessment using a Chilean case study. Food Policy 75:68-79

Davidson J, Barrows F, Kennet B, Good C, Schroyer K, Summerfelt S (2016) Effects of feeding a fishmeal-free versus a fishmeal-based diet on post-smolt Atlantic Salmon Salmo salar performance, water quality, and waste production in recirculation aquaculture systems. Aquac Eng 74:38-51

Drakeford B, Pascoe S (2008) Substitutability of fishmeal in diets for salmon and trout: a meta-analysis. Aquac Econ Manag 12:155-175

EUMOFA (2017) Monthly highlights no 4. Retrieved from: http://www.eumofa.eu/documents/20178/102199 /Monthly+Highlights+-+No.+4-2017.pdf. Accessed 13 May 2019

FAO (2018) The state of world fisheries and aquaculture 2018. Food and agriculture organisation of the United Nations, Rome

FAO (2019) Productivity growth continues in global salmon sector despite price volatility. Retrieved from: http://www.fao.org/in-action/globefish/market-reports/resource-detail/en/c/1176223/. Accessed 15 May 2019

Gillett R (2009) Fisheries in the economies of Pacific Island countries and territories. Asian Development Bank, Manila

Global Salmon Initiative (2018) https://globalsalmoninitiative.org/en/

Guttormsen AG (2002) Input factor substitutability in Salmon aquaculture. Mar Resour Econ 17:91-102

Intrafish (2018) Salmon market prices. https://www.intrafish.com/topic/salmon. Accessed 14 May 2019

Leon-Munoz J, Urbina M, Garreaud R, Iriarte J (2018) Hydroclimatic conditions trigger record harmful algal bloom in western Patagonia (summer 2016). Sci Rep 8:1330

Lozano I, Diaz NF, Munoz S, Riquelme C (2018) Antibiotics in Chilean aquaculture: a review. In: Savic S (ed) Antibiotic use in animals, pp 25-43 Retrieved from http://www.intechopen.com/books/antibiotic-use-in-animals. Accessed 15 May 2019

Naylor RL, Goldberg RJ, Primavera JH, Kautsky N, Beveridge MC, Clay J, Folke C, Lubchenco J, Mooney H, Troell M (2000) Effect of aquaculture on world fish supplies. Nature 405:1017-1024

Naylor RL, Hardt RW, Bureau DP, Chiu A, Elliot M, Farrell AP, Forster I, gatlin DM, Goldburg RJ, Hua K, Nichols PD (2009) Feeding aquaculture in an era of finite resources. Proc Natl Acad Sci 106(36):15103-15110

Olesen I, Myhr A, Rosendal G (2011) Sustainable aquaculture: are we getting there? Ethical perspectives on Salmon farming. J Agric Environ Ethics 24(4):381-408

Osmundsen TC, Almklov P, Tveterås R (2017) Fish farmers and regulators coping with the wickedness of aquaculture. Aquac Econ Manag 21(1):163-183

Pratoomyot J, Bendiksen EÅ, Bell JG, Tocher DR (2011) Effects of increasing replacement of dietary fishmeal with plant protein sources on growth performance, and body lipid composition of Atlantic salmon (Salmo salar L.). Aquaculture 316:44-52

Salze G, McLean E, Battler PR, Schwartz MH, Craig S (2010) Use of soy protein concentrate and novel ingredients in the total elimination of fish meal and fish oil in diets for juvenile cobia, (Rachycentron canadum). Aquaculture 298:294-299

Sealey WM, Hardy RW (2011) Evaluation of $100 \%$ fish meal substitution with chicken concentrate, protein poultry by-product blend, and chicken and egg concentrate on growth and disease resistance of juvenile rainbow trout (Oncorhynchus mykiss). J World Aquacult Soc 42(1):46-55

Tacon A, Metian S (2008) Global overview of the use of fish meal and fish oil in industrially compounded aquafeeds. Trends and future prospects. Aquaculture 285:146-158 
Taranger GL, Karlsen O, Bannister RG et al (2015) Risk assessment of the environmental impact of Norwegian Atlantic salmon farming. ICES J Mar Sci 72(3):997-1021

Tecklin D (2016) Sensing the limits of fixed marine property rights in changing coastal ecosystems: Salmon aquaculture concessions, crisis, governance challenges in southern Chile. J Int Wildl Law Policy 19(4):284-300

Tveterås R, Heshmati A (2002) Patterns of productivity growth in the Norwegian salmon farming industry. RISEC: Int Rev Econ Bus 2:367-363

Tveteras S, Asche F, Bellemare MF, Smith MD, Guttormsen AG, Lem A, Lien K, Vannucini S (2012) Fish is food - the FAO's fish Price index. PLoS One 7(5):e36731

Wang X, Olsen LM, Reitan KI, Olsen Y (2012) Discharge of nutrient wastes from salmon farms: environmental effects, and potential for integrated multi-trophic aquaculture. Aquac Environ Interact 2:267-283

Ytrestøyl T, Aas TS, Åsgård T (2015) Utilization of feed resources in production of Atlantic salmon (Salmo salar). Aquaculture 448:365-374

\section{Data references}

United Nations, Department of Economic and Social Affairs, Population Division (2017). World population prospects: the 2017 revision, key findings and advance tables. Working paper no. ESA/P/WP/248

World Bank (2018) Data - World Bank Open Data. https://data.worldbank.org/country/chile

Publisher's note Springer Nature remains neutral with regard to jurisdictional claims in published maps and institutional affiliations.

\section{Affiliations}

\section{Exequiel Gonzalez Poblete ${ }^{1} \cdot$ Benjamin M. Drakeford $^{2} \cdot$ Felipe Hurtado Ferreira $^{1}$ • Makarena Garrido Barraza ${ }^{1}$ • Pierre Failler ${ }^{2}$}

1 Facultad de Ciencias del Mar y Geografía, Pontificia Universidad Católica de Valparaíso, Valparaíso, Chile

2 Economics and Finance Subject Group, Portsmouth Business School, University of Portsmouth, Portland Building, Portland Street, Portsmouth PO1 3AH, UK 